\title{
Uji Antimikroba Daging Buah (Carica pubescens) Matang Terhadap Bakteri Staphylococcus aureus Metode Kirby Bauer Secara In Vitro
}

\section{Antimicrobial Test Carica pubescens Fruit Mature in Staphylococcus aureus Bacteria In Vitro with Kirby Bauer Method}

\author{
Umarudin $^{1 *}$, Floreta Fiska Yuliarni ${ }^{2}$ \\ ${ }^{1,2}$ Akademi Farmasi Surabaya, Surabaya, Indonesia \\ *Koresponden: umarsains54@gmail.com
}

\begin{abstract}
Abstrak
Staphylococcus aureus dapat menyebabkan infeksi kulit seperti bisul atau abses dan jerawat. Pengunaan antibiotik yang tidak tepat menyebabkan munculnya $S$. aureus yang resisten terhadap antibiotik karena adanya perubahan genetik. Permasalahan yang disebabkan akibat penggunaan antibiotik yang tidak tepat tersebut menimbulkan upaya eksplorasi senyawa antibakteri yang lebih efektif dengan dampak yang minimal. Salah satu tanaman yang bersifat sebagai antibakteri adalah daging buah karika (Carica pubescens). Penelitian ini dilakukan secara true eksperimental. S. aureus diperoleh dari laboratorium Universitas Airlangga dan diidentifikasi berdasarkan sifat biakan, pewarnaan Gram, uji biokimiawi dan uji gula-gula. Isolat selanjutnya diuji antimikroba terhadap ekstrak daging buah $C$. pubescens. Hasil penelitian menunjukkan bahwa bakteri yang tumbuh, dapat memfermentasi plat mannitol salt agar, sel berbentuk bulat bergerombol, bersifat Gram + , dapat memfermentasi maltosa dan laktosa, dapat menkoagulasi plasma kelinci dan bereaksi positif terhadap uji clumping faktor dan uji Voges Proskouer. Pada penelitian ini, hasil uji menunjukkan bahwa ekstrak daging buah Carica pubescens dengan konsentrasi 20\%, 40\%, dan 60\% memiliki daya hambat terhadap Staphylococcus aureus. Daya hambat terbesar terdapat pada konsentrasi $60 \%$. Semakin kecil konsentrasi ekstrak C. pubescens, semakin kecil daya hambatnya terhadap S. aureus.
\end{abstract}

Kata kunci: Staphylococcus aureus, Ekstrak Daging Buah Karika (Carica pubescens), antibakteri.

\begin{abstract}
Staphylococcus aureus can cause skin infections such as boils or abscesses and acne. Improper use of antibiotics causes the emergence of S. aureus that is resistant to antibiotics because of genetic changes. The problems caused by inappropriate use of antibiotics have led to more effective exploration of antibacterial compounds with minimal impact. One of the plants that are as antibacterial is karika fruit (Carica pubescens). In this study, it was carried out in a true experimental manner. S. aureus was isolated from the laboratory Airlangga University and was identified based on culture characteristics, Gram staining, biochemical tests and confectionery tests. The isolates were then tested for antimicrobials against C. pubescens fruit extract. The results showed that the isolation of bacteria that grew and could ferment the mannitol salt agar plates, clustered rounded cells, Gram +, fermented maltose and lactose, coagulated rabbit plasma and reacted positively to the clumping factor test and Voges Proskouer test. In this study, test results showed that Carica pubescens fruit extracts with concentrations of 20\%, 40\%, and 60\% had inhibitory properties against Staphylococcus aureus. The greatest inhibition is found at a concentration of $60 \%$. The smaller the concentration of C. pubescens extract, the smaller the inhibitory power against $S$. aureus.
\end{abstract}

Keywords: Staphylococcus aureus, Carica Pubescens Fruit Extract, Antibacterial.

\section{PENDAHULUAN}

Staphylococcus aureus adalah bakteri Gram positif yang berbentuk kokus. Bakteri tersebut merupakan flora normal pada kulit manusia, tetapi juga merupakan salah satu 
penyebab infeksi akibat adanya luka (Brooks, dkk., 2013). Bakteri tersebut tahan terhadap kondisi kering dan toleran pada konsentrasi garam yang relatif tinggi. Karakter tersebut yang menyebabkan $S$. aureus dapat hidup pada kulit manusia atau sel epitel pernafasan manusia dan tidak menyebabkan penyakit yang berbahaya. Namun, menjadi berbahaya apabila masuk ke dalam jaringan kulit atau darah sehingga menyebabkan infeksi (Hogg, 2013; Tortora dkk., 2013). Staphylococcus aureus dapat menyebabkan penyakit pada kulit seperti jerawat, bisul, atau bisul bernanah serta infeksi saluran pernapasan yang parah (Hogg, 2013). Penggunaan antibiotik yang tidak tepat menyebabkan munculnya Staphylococcus aureus yang resisten terhadap antibiotik, seperti Meticillin-Resistant Staphylococcus aureus (MRSA) (Tortora dkk., 2013).

Permasalahan yang disebabkan akibat penggunaan antibiotik yang tidak tepat tersebut menimbulkan upaya eksplorasi senyawa antibakteri yang lebih efektif dengan dampak yang minimal. Salah satu upaya adalah dengan menggunakan tanaman karika (Carica pubescens). Bagian yang digunakan diantaranya kulit, daun, biji dari karika (Astuti dan Hadi, 2018; Sugiyarto dkk., 2019). Buah karika berwarna kuning seperti buah pepaya, tetapi dengan ukuran lebih kecil. Buah yang kuning menunjukkan adanya kandungan flavonoid dan betakaroten. Flavonoid adalah senyawa kimia sebagai anti inflamasi, sedangkan betakaroten merupakan salah satu antioksidan untuk mengurangi reaksi radikal bebas dalam jaringan (Magfiroh, 2017). Kandungan karbohidrat buah karika, baik pada daging buah maupun salut biji dari bagian atas, tengah, bawah (kurang matang hingga semakin matang) polanya menurun kemudian meningkat, sedangkan untuk serat kasar mengalami penurunan (Fitriningrum dkk., 2013). Daun karika mengandung senyawa alkaloid, fenol, dan flavonoid, sedangkan biji karika mengandung senayawa alkaloid, fenol, dan flavonoid dengan pelarut etil asetat dan mengandung alkaloid dan tannin dengan pelarut n-heksan (Indranila dan Ulfah, 2015; Sugiyarto dkk., 2019).

Penelitian aktivitas antibakteri dengan menggunakan kulit dan biji buah karika yang dilakukan oleh Sugiyarto dkk. (2019) menunjukkan bahwa terjadi zona hambat pada bakteri E. coli, S. aureus, dan S. flexneri dengan menggunakan pelarut etil asetat, sebaliknya tidak menunjukkan aktivitas antibakteri pada bakteri-bakteri tersebut dengan menggunakan pelarut air. Hasil penelitian Astuti dan Hadi (2018), menunjukkan bahwa ekstrak daun karika dengan konsentrasi $100 \%$ dapat menghambat bakteri Vibrio cholerae dan Shigella dysentriae yang ditunjukkan dengan adanya zona hambat sebesar $2,6 \mathrm{~cm}$ dan $1,4 \mathrm{~cm}$ berturut-turut untuk 
bakteri $V$. cholerae dan $S$. dysentriae. Besar daya hambat yang ditunjukkan pada bakteri $V$. cholerae hampir sama dengan antibiotik yang digunakan sebagai kontrol pada penelitian tersebut. Buah karika mengandung senyawa flavonoid, tannin dan terpenoid. Senyawa tersebut bersifat sebagai antibakteri salah satunya melalui mekanisme merusak dinding sel bakteri sehingga bakteri akan lisis. Penelitian-penelitian yang telah dilakukan menggunakan bagian kulit, biji, dan daun karika, tetapi penelitian yang menggunakan daging buah yang muda dan matang pada bakteri S. aureus belum diteliti. Penelitian ini bertujuan untuk mengetahui daya hambat dari ekstrak daging buah Carica pubescens yang matang terhadap bakteri S. aureus.

\section{METODE PENELITIAN}

Jenis penelitian ini adalah true eksperimen. Penelitian dilakukan pada bulan Maret-Juni 2019. Tempat penelitian di Laboratorium Mikrobiologi Akademi Farmasi Surabaya. Alat yang digunakan pada penelitian ini adalah kompor listrik, erlenmeyer, batang pengaduk, labu ukur, pisau, blender, oven, timbangan digital, gelas ukur, saringan 100 mesh, cawan petri, cawan porselen, pinset, autoklaf, botol vial, swab steril, kertas cakram, tabung reaksi, bunsen, jarum ose, laminar air flow, rotary evaporator, beaker glass. Bahan yang digunakan dalam penelitian ini adalah buah karika matang, etanol 96\%, antibiotik ampisilin, akuades, media Nutrient Broth (NB) dan media Muller Hinton (MH) untuk kultur bakteri.

\section{Pembuatan ekstrak}

Buah karika matang ditimbang 100 gram, kemudian ditambahkan pelarut etanol 96\% sebanyak 1 liter selama 3 hari diaduk sesekali dan dilakukan penyaringan, setelah itu dilakukan evaporasi untuk mendapatkan ekstrak kental karika matang.

\section{Sterilisasi Alat}

Alat-alat seperti cawan petri dan tabung reaksi dibungkus dengan aluminium foil dan disterilkan dalam oven dengan suhu $180^{\circ} \mathrm{C}$ selama 120 menit. Media disterilisasi menggunakan autoklaf pada suhu $121^{\circ} \mathrm{C}$ selama 20 menit. Pinset dan ose disterilisasi dengan cara dibakar menggunakan bunsen.

\section{Pembuatan Konsentrasi Ekstrak dari Larutan Induk}

Konsentrasi ekstrak sebesar 20\% dibuat dengan cara mengambil $2 \mathrm{ml}$ larutan induk, dimasukkan ke dalam labu ukur $10 \mathrm{ml}$, ditambah akuades steril sampai tanda batas, dikocok 
sampai homogen, kemudian dimasukkan ke dalam botol vial. Konsentrasi ekstrak sebesar $40 \%$ dibuat dengan cara mengambil $4 \mathrm{ml}$ larutan induk, dimasukkan ke dalam labu ukur 10 ml, ditambah akuades steril sampai tanda batas, dikocok sampai homogen, kemudian dimasukkan ke dalam botol vial. Konsentrasi sebesar 60\% dibuat dengan cara mengambil 6 $\mathrm{ml}$ larutan induk, dimasukkan ke dalam labu ukur $10 \mathrm{ml}$, ditambah akuades steril sampai tanda batas, dikocok sampai homogen, kemudian dimasukkan ke dalam botol vial.

\section{Perendaman Kertas Cakram Dalam Masing-masing Konsentrasi Ekstrak}

Kertas cakram direndam ke dalam masing-masing konsentrasi ekstrak. Perendaman dilakukan selama 20 menit, hingga terserap penuh pada tiap-tiap kertas cakram. Hal yang sama juga dilakukan untuk kontrol negatif dan kontrol positif.

\section{Uji Aktivitas Ekstrak Buah Karika Matang terhadap Pertumbuhan Bakteri Staphylococcus aureus.}

Swab steril dicelupkan ke dalam biakan bakteri di media NB. Biakan bakteri yang berlebih, dikurangi dengan cara menekan dan memutar swab kuat-kuat pada sisi tabung. Swab diusapkan ke seluruh permukaan media MH. Swab juga diusapkan ke sekeliling pinggiran permukaan agar. Biakan bakteri di cawan petri dibiarkan beberapa menit pada temperatur kamar dalam keadaan tertutup. Kertas cakram yang berisi masing-masing konsentrasi ekstrak diletakkan pada media MH dengan menggunakan pinset steril. Media diletakkan pada inkubator pada suhu $37^{\circ} \mathrm{C}$ selama 24 jam. Diamater zona hambat diukur dengan jangka sorong setelah inkubasi 24 jam. Zona hambat dicatat dalam satuan $\mathrm{mm}$, kemudian hasil yang didapat diinterpretasikan.

\section{Analisis Data}

Data yang didapatkan, dihitung rata-ratanya, kemudian dibuat diagram batang untuk memudahkan dalam menginterpretasikan data. Data yang diperoleh kemudian dianalisis secara desktiptif.

\section{HASIL DAN PEMBAHASAN}

Pada penelitian ini menggunakan daging buah karika matang (Carica pubescens) dalam kondisi segar dan dilakukan pencucian supaya terpisah dari kotoran, kemudian diblender yang bertujuan untuk memperkecil ukuran buah karika serta untuk mempermudah proses maserasi. Menurut Khasanah (2015) menyatakan bahwa buah karika matang yang diblender merupakan suatu usaha untuk memperluas permukaan sehingga zat aktif yang tergantung mudah larut 
dengan baik. Pelarut yang digunakan pada penelitian ini dengan menggunakan etanol 96\%. Menurut Suamiati, dkk. (2016), pelarut etanol 96\% bersifat polar sehingga dapat menarik senyawa- senyawa polar seperti flavonoid, saponin dan tanin.

Hasil dari ekstraksi diperoleh rendemen sebesar 10,12\%. Ekstrak buah karika matang (Carica pubescens), kemudian dievaporasi dengan menggunakan alat rotary evaporator pada suhu $40^{\circ} \mathrm{C}$. Tujuan dilakukan evaporasi adalah untuk memisahkan ekstrak dengan cairan penyarinya sehingga didapatkan ekstrak yang lebih pekat atau ekstrak yang lebih kental (Harli, 2016). Ekstrak hasil evaporasi tersebut kemudian diuapkan di dalam oven pada suhu $40^{\circ} \mathrm{C}$ selama 7 hari, hal ini dilakukan untuk menghilangkan pelarut yang masih tersisa (Hanifah, 2015). Pemilihan suhu $40^{\circ} \mathrm{C}$ dilakukan agar tidak terjadi kerusakan struktur senyawa metabolit sekunder yang terkandung dalam buah karika matang (Carica pubescens) akibat pemanasan.

Ekstrak etanol $96 \%$ buah karika matang (Carica pubescens) yang sudah diperoleh dilakukan uji bebas etanol dengan menambahkan asam asetat dan asam sulfat pekat. Uji bebas etanol tersebut bertujuan untuk memastikan bahwa ekstrak yang akan diuji telah bebas dari etanol (Wulandari, 2017). Hasil ekstrak etanol 96\% buah karika matang (Carica pubescens) yang sudah bebas etanol dilakukan pengujian bakteri Staphylococcus aureus dengan metode Kirby Bauer secara in vitro.

Hasil pengujian ekstrak C. pubescens dengan konsentrasi 20\%, 40\%, dan 60\% terhadap bakteri S. aureus menunjukkan adanya zona hambat pada semua konsentrasi. Zona hambat adalah daerah bening di sekitar kertas cakram. Hal tersebut menunjukkan bahwa tidak terdapat pertumbuhan bakteri di sekitar kertas cakram. Terdapat perbedaan besarnya zona hambat dari masing-masing konsentrasi. Perbedaan besarnya zona hambat pada masingmasing konsentrasi tersebut ditunjukkan pada Tabel 1 dan Gambar 1.

Tabel 1. Hasil Pengukuran Zona Hambat Ekstrak C. pubescens terhadap S. aureus.

\begin{tabular}{lc}
\hline \multicolumn{1}{c}{ Bahan uji } & Diameter zona hambat (mm) \\
\hline Ekstrak buah karika matang 20\% & 8,3 \\
Ekstrak buah karika matang 40\% & 13,0 \\
Ekstrak buah karika matang 60\% & 14,7 \\
Kontrol positif & 25,0 \\
Kontrol negatif & 6,0 \\
\hline
\end{tabular}



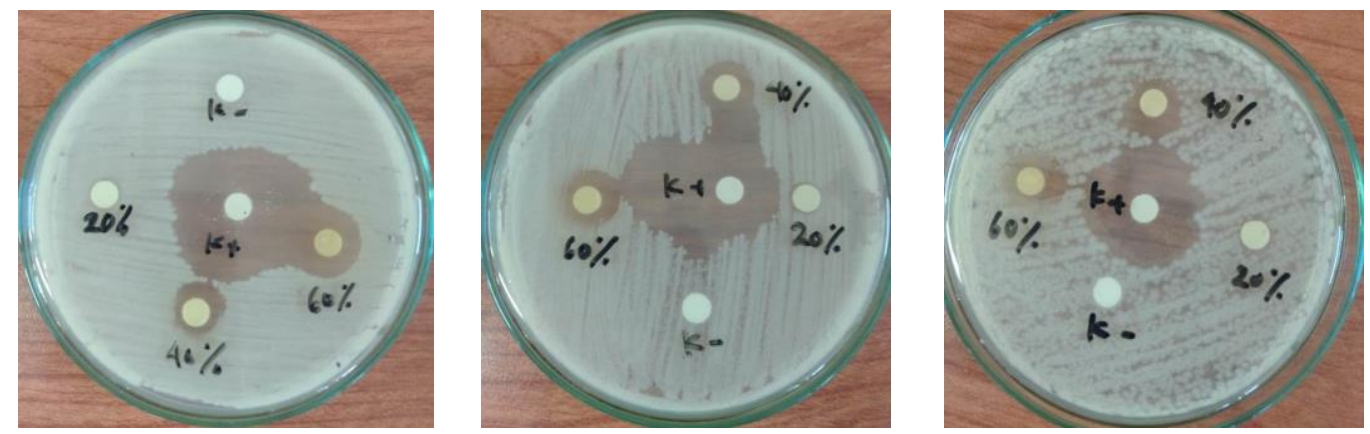

Gambar 1. Zona Hambat yang Terbentuk dari Ekstrak C. pubescens pada Konsentrasi 20\%, $40 \%$, dan $60 \%$ terhadap S. aureus.

Keterangan

$\mathrm{K}(-)$

$\mathrm{K}(+)$

20,40, dan $60 \%$
: kontrol negatif akuades

: kontrol positif ampisilin

: ekstrak daging buah karika matang

Ekstrak C. pubescens dengan konsentrasi $60 \%$ menunjukkan zona hambat paling tinggi, yaitu sebesar 14,7 mm dibandingkan dengan zona hambat yang terbentuk dari ekstrak $C$. pubescens dengan konsentrasi $20 \%$ dan $40 \%$, yaitu sebesar 13,0 dan 8,3 mm (Tabel 1. dan Gambar 2.). Pada Gambar 2, terlihat bahwa semakin kecil konsentrasi ekstrak C. pubescens, semakin kecil daya hambatnya terhadap S. aureus, begitu juga sebaliknya. Semua konsentrasi ekstrak C. pubescens lebih kecil apabila dibandingkan dengan kontrol positif, yaitu antibiotik ampisilin. Zona hambat yang terbentuk pada antibiotik ampisilin terhadap S. aureus sebesar 25,0 mm. Namun, zona hambat pada antibiotik ampisilin masih terlihat beberapa koloni bakteri yang tumbuh, sedangkan zona hambat pada semua konsentrasi dari ekstrak buah karika tidak terlihat adanya koloni yang tumbuh.

Penelitian yang dilakukan oleh Umami (2018), menyebutkan bahwa biji karika pada konsentrasi $50 \%$ memiliki zona hambat terhadap bakteri Salmonella typhi sebesar $10 \mathrm{~mm}$, sedangkan pada konsentrasi 12,5 dan 25\% tidak terdapat zona hambat. Perbedaan penelitian ini dibandingkan penelitian Umami adalah pada penelitian ini menggunakan daging buah karika matang dan pelarut untuk ekstraksi yang digunakan adalah etanol 96\%, bakteri uji $S$. aureus, konsentrasi yang digunakan 20\%, 40\%, dan 60\% serta uji daya hambat menggunakan kertas cakram, sedangkan pada penelitian Umami menggunakan biji buah karika, pelarut untuk ekstraksi adalah etanol 70\%, bakteri uji S. typhi, konsentrasi yang digunakan 12,5\%, $25 \%$, dan $50 \%$ serta uji daya hambat menggunakan sumuran. Dari hasil yang didapatkan, 
pada penelitian ini dengan konsentrasi $40 \%$ sudah dapat menghambat S. aureus sebesar 13 mm, sedangkan pada penelitian Umami (2018) pada konsentrasi 50\% baru dapat menghambat S. typhi sebesar $10 \mathrm{~mm}$. Apabila hanya dengan membandingkan konsentrasi yang digunakan, dapat dikatakan bahwa zona hambat yang terbentuk pada penelitian ini lebih besar jika dibandingkan dengan penelitian sebelumnya.

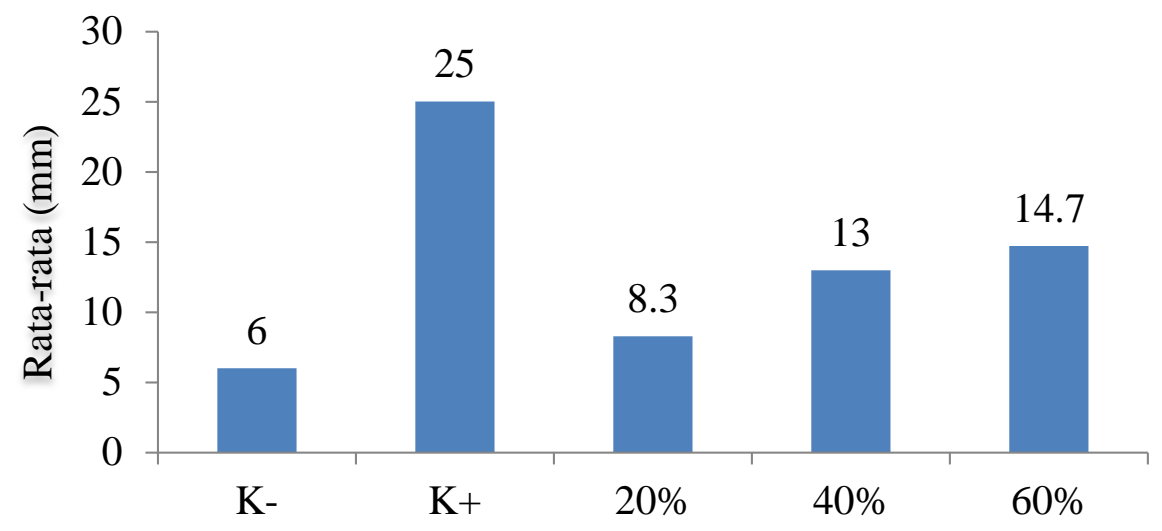

Gambar 2. Perbandingan Besar Zona Hambat yang Terbentuk dari Ekstrak C. pubescens terhadap $S$. aureus.

Keterangan

$\mathrm{K}(-) \quad$ : kontrol negatif akuades

$\mathrm{K}(+) \quad$ : kontrol positif ampisilin

20,40 , dan $60 \% \quad$ : ekstrak daging buah karika matang

Pada penelitian yang dilakukan oleh Astuti dan Hadi (2018), menunjukkan bahwa ekstrak daun karika mempunyai kemampuan untuk menghambat bakteri Vibrio cholerae dan Shigella dysentriae. Zona hambat ekstrak daun karika terhadap bakteri V. cholerae pada konsentrasi 12,5\%, 25\%, 50\%, dan 100\% secara berturut-turut adalah 19 mm, 20 mm, $23 \mathrm{~mm}$, dan $26 \mathrm{~mm}$, sedangkan terhadap bakteri S. dysentriae pada konsentrasi 12,5\%, 25\%, 50\%, dan 100\% secara berturut-turut adalah $7 \mathrm{~mm}, 7 \mathrm{~mm}, 8 \mathrm{~mm}$, dan $14 \mathrm{~mm}$. Pada penelitian tersebut menggunakan daun karika, pelarut etanol 70\%, bakteri yang digunakan adalah $V$. cholerae dan S. dysentriae, serta konsentrasi yang digunakan adalah 12,5\%, 25\%, 50\%, dan $100 \%$. Penelitian tersebut memiliki persamaan dengan penelitian ini, yaitu menggunakan kertas cakram untuk uji daya hambat. Perbedaannya adalah pada penelitian ini menggunakan daging buah karika, pelarut etanol 96\%, bakteri S. aureus dan konsentrasi yang digunakan adalah 20\%, 40\%, dan 60\%. Zona hambat pada penelitian ini dengan konsentrasi 40\% (sebesar 13 mm) lebih besar dibandingkan dengan penelitian Astuti dan Hadi pada konsentrasi 50\% 
(sebesar $8 \mathrm{~mm}$ ) terhadap bakteri S. dysentriae, tetapi lebih kecil pada konsentrasi $50 \%$ (sebesar $23 \mathrm{~mm}$ ) terhadap bakteri $V$. cholerae.

Menurut Sugiyarto, dkk., (2019), zona hambat yang terbentuk dapat dipengaruhi oleh beberapa faktor, diantaranya adalah komponen antibakterial yang terdapat dalam ekstrak $C$. pubescens, kemampuan ekstrak untuk berdifusi ke dalam cakram, dan konsentrasi ekstrak. Analisis fitokimia yang dilakukan oleh Sugiyarto dkk., (2019), kulit C. pubescens yang diekstrak dengan menggunakan heksan mengandung senyawa alkaloid dan tannin, sedangkan Menurut hasil uji kulit $C$. pubescens yang diekstrak dengan etil asetat mengandung flavonoid, tannin, dan fenol. Hasil penelitian Magfiroh (2017) menyatakan bahwa kandungan buah daging buah karika adalah flavonoid. Hal ini dibuktikan juga pada penelitian yang telah dilakukan positif mengandung flavonoid. Flavonoid merupakan salah satu senyawa golongan dari fenol (Karou et al., 2005). Daya hambat uang diakibatkan melalui mekanisme kerja dalam menghambat pertumbuhan bakteri dengan cara inaktivasi protein (enzim) pada membran sel.

Menurut Susanti (2008), menyatakan bahwa fenol berikatan dengan protein melalui ikatan hidrogen sehingga dapat mengakibatkan struktur protein menjadi rusak. Dimana sebagian besar struktur dinding sel dan membran sitoplasma bakteri mengandung protein dan lemak. Ketidakstabilan pada dinding sel dan membran sitoplasma bakteri menyebabkan fungsi permeabilitas selektif, fungsi pengangkutan aktif, pengendalian susunan protein dari sel bakteri menjadi terganggu, yang akan berakibat pada lolosnya makromolekul, dan ion dari sel. Sehingga sel bakteri menjadi kehilangan bentuknya, dan terjadilah lisis yang berakibat pada kematian bakteri S.aureus.

Setiap golongan senyawa yang terdapat pada daging buah matang karika memberikan efek yang berbeda dalam menghambat pertumbuhan bakteri. Adanya perbedaan aktivitas yang terjadi disebabkan oleh metabolit sekunder yang terkandung memiliki efek sinergis yang berbeda tergantung dari sifat dan morfologi dari bakteri tersebut. Berdasarkan mekanisme kerjanya, antibakteri dibedakan menjadi bakteriostatik dan bakterisidal. Antibakteri bakteriostatik adalah zat yang bekerja menghambat pertumbuhan bakteri, sedangkan antibakteri bakterisida adalah zat yang bekerja mematikan bakteri.

Hasil penelitian menunjukkan bahwa ekstrak daging matang buah karika bersifat bakterisida. Sedangkan kontrol positif bersifat bakteriostatik. Hal ini ditandai disekeliling disk masih ada bakteri sehingga ampisilin pada bakteri S.aureus hanya menghambat pertumbuhan 
bakteri tersebut. Sedangkan kontrol negative tidak ada zona hambat karena aquadest steril tidak bersifat sebagai antibakteri, namun pada kontrol positif terdapat zona hambat. Hal ini dikarenakan ampisilin yang memiliki spektrum luas. Zona hambat dari perlakuan ampisilin pada penelitian ini adalah sebesar $25 \mathrm{~mm}$ yang menunjukan bahwa ampisilin yang diuji kategori sensitif berdasarkan standart CLSI. Mekanisme kerja dari ampisilin adalah dengan menghambat biosintesis dari mukopeptida dinding sel bakteri saat bakteri bermultiplikasi (Tong et al., 2015). Ampisilin, memiliki senyawa-senyawa kimia yang lebih kuat dalam menghambat pertumbuhan bakteri Staphylococcus aureus dibandingkan dengan ekstrak daging matang buah karika. Berdasarkan uraian diatas pada penelitian ini pengulangan dalam berbagai konsentrasi menunjukkan aktivitas antibakteri dengan terbentuknya zona hambat. Hal ini membuktikan hipotesis dalam penelitian ini bahwa ekstrak etanol daging matang buah C. pubescens, terhadap Staphylococcus aureus dengan metode Kirby-Bauer.

\section{KESIMPULAN}

Ekstrak daging matang buah Carica pubescens dengan konsentrasi 20\%, 40\%, dan 60\% memiliki daya hambat terhadap Staphylococcus aureus. Daya hambat terbesar terdapat pada konsentrasi $60 \%$. Semakin kecil konsentrasi ekstrak daging matang buah $C$. pubescens, semakin kecil daya hambatnya terhadap S. aureus, begitu juga sebaliknya.

\section{REFERENSI}

Astuti, T.D., dan Hadi, W.S., 2018. Potensi Ekstrak Daun Carica pubescens Sebagai Alternatif Antidiare Bakteri Vibrio chloreae dan Shigella dysentriae. Jurnal Teknologi Laboratorium, Vol. 7(2): 61-69.

Brooks, G. F., Carroll, K. C., Butel, J. S., Morse, S. A., \& Mietzner, T. A., 2013. Jawetz, Melnick, \& Adelberg's, Medical Microbiology, $26^{\text {th }}$ edition. New York: The McGrawHill Companies, Inc.

Fitriningrum, R., Sugiyarto, dan Susilowati, A., 2013. Analisis kandungan karbohidrat pada berbagai tingkat kematangan buah karika (Carica pubescens) di Kejajar dan Sembungan, Dataran Tinggi Dieng, Jawa Tengah. Bioteknologi, Vol. 10 (1): 6-14.

Hanifah, N.Z., 2015. Uji Toksisitas Akut Ekstrak Metanol Daun Sirsak (Annona muricata L) Terhadap Larva Artemia salina Leach Dengan Metode Brine Shrimp Lethality Test (BSLT). Skripsi. UIN Hidayatullah. Jakarta. 
Harli, S.A., 2016. Uji Toksisitas Fraksi Ekstrak Etanol Daun Pedang-Pedang (Sansevieria Trifasciata Prain) Terhadap Larva Udang (Artemia Salina Leach) Dengan Menggunakan Metode Brine Shrimp Lethality Test (BSLT). Skripsi. Universitas Islam Negeri Alauddin Makassar. Makassar.

Hogg, S., 2013. Esstential Microbiology, $2^{\text {nd }}$ edition. West Sussex: John Wiley \& Sons, Ltd.

Indranila \& M. Ulfah. 2015. Uji Aktivitas Antioksidan Ekstrak Etanol Daun Karika (Carica pubescens) dengan Metode DPPH Beserta Identifikasi Senyawa Alkaloid, Fenol dan Flavonoid. Prosiding Seminar Nasional Peluang Herbal Sebagai Alternatif Medicine: 105-111.

Karou, D., Dicko, M.H., Simpore, J., and Traore, A.S., 2005. Antioxidant and Antibacterial Activities of Polyphenols From Etnomedicinal Plant Of Burkina Faso. African Journal Of Biotecnology. 4 (8): 823-828.

Khasanah, U., 2015. Pengaruh Perlakuan Pendahuluan Terhadap Karakteristik Mutu Minyak Atsiri Daun Jeruk Purut (Citrus hystrix DC). J Aplikasi Teknologi Pangan. Vol. 4 (2): 48-55.

Magfiroh, U.L., 2017. Faktor Ketinggian Tempat Terhadap Sintesis Vitamin Buah Carica (Carica pubescens). Prosiding Seminar Nasional Pendidikan Biologi dan Biologi: B-69 $-\mathrm{B}-74$.

Sugiyarto, D., Novalina, Susilowati, A., \& Sasongko, H., 2019. Antibacterial Activity of Ethyl Acetate and n-hexane Fractions. AIP Conference Proceedings: 050005-1050005-7.

Sumiati T., Ferry E., Rina, A. P., 2016. Uji Toksisitas Ekstrak Daun Sirsak (Annona muricata L.) yang Berpotensi Sebagai Antikanker. Jurnal Farmamedika. Vol.1 (2): 84-91.

Susanti, A., 2008. Daya antibakteri ekstrak etanol daun beluntas (Pluchea indica less) terhadap Escherichia coli secara in vitro. Jurnal universitas airlangga. Vol. 1 (1): 1-10.

Tong,S.Y.C, Davis, J.S, Eichenberger, E, Holland, T.L, \& Fowler, V. G., 2015. Staphylococcus aureus Trisia A, Philyria R, \& Toemon, AN, 2018, Uji Antibakteri Daun Kalanduyung terhadap Staphylococcus aureus. Journal ASM. Vol. 15 (4): 105120.

Tortora, G.J., Funke, B.R., \& Case, C.L., 2013. Microbiology an Introduction, $11^{\text {th }}$ edition. New York: Pearson Education, Inc.

Umami, N. R., 2018. Uji Aktivitas Antibakteri Ekstrak Etanol 70\% Biji Carica (Carica pubescens) terhadap Bakteri Salmonella thypi. Skripsi. Universitas Muhammadiyah Surakarta, Surakarta.

Wulandari, R. A. S., 2017. Formulasi Dan Uji Aktivitas Antibakteri Staphylococcus epidermidis Sediaan Mikroemulsi Ekstrak Daun Kersen (Muntingia calabura Linn.) Dengan Fase Minyak Isopropil Mirystate. Skripsi. Universitas Islam Negeri Maulana Malik Ibrahim. Malang. 